University of Nebraska - Lincoln

DigitalCommons@University of Nebraska - Lincoln

Agronomy \& Horticulture -- Faculty Publications

Agronomy and Horticulture Department

4-1950

\title{
Effects of Different Intensities of Grazing on Depth and Quantity of Roots of Grasses
}

J. E. Weaver

University of Nebraska-Lincoln

Follow this and additional works at: https://digitalcommons.unl.edu/agronomyfacpub

Part of the Plant Sciences Commons

Weaver, J. E., "Effects of Different Intensities of Grazing on Depth and Quantity of Roots of Grasses" (1950). Agronomy \& Horticulture -- Faculty Publications. 505.

https://digitalcommons.unl.edu/agronomyfacpub/505

This Article is brought to you for free and open access by the Agronomy and Horticulture Department at DigitalCommons@University of Nebraska - Lincoln. It has been accepted for inclusion in Agronomy \& Horticulture -Faculty Publications by an authorized administrator of DigitalCommons@University of Nebraska - Lincoln. 


\title{
Effects of Different Intensities of Grazing on Depth and Quantity of Roots of Grasses ${ }^{1}$
}

\author{
J. E. WEAVER \\ Professor of Plant Ecology \\ University of Nebraska, Lincoln, Nebraska
}

$\mathbf{T}$ VHE writer has been interested in prairies, pastures, and root depth and distribution over a period of many years. He had the privilege of examining these relationships in the Palouse prairie of Washington long ago while numerous representative areas still remained in a virgin condition $(5,6)$. Extensive studies have been made in the hardlands of Colorado, Kansas, and Nebraska many years before, during, and following the great drought of 1933-40 $(7,8,1,11)$. Vegetation and root habits have been studied in sand hills $(7,8,4)$, in bluffs of wind-blown loess (12), and wet soils of lowland. The trench and hand pick method was employed throughout and roots in prairie and pasture were measured, compared, and sketched in the field. Their depth, spread, and chief characteristics were recorded. Only general consideration was given to soil type. At that time there was no method of quantitatively comparing one root system with another or the roots from one soil with those of the same species from a different soil. The need for such a method has been felt for a long time and lack of one that could be put into general use has probably greatly retarded root studies.

This paper is concerned with a new quantitative method of studying root-soil relations and particularly its application to the effects on the underground plant parts brought about by grazing. The

1 Contribution No. 155 from the Department of Botany, University of Nebraska. This study was aided by a grant from the University Research Council, University of Nebraska. method of obtaining a sample of the entire root system from the soil surface to the deepest root tips is a modification of the direct or trench method fully described in 1926 (9). It consists in the digging of a trench to the desired depth in a particular soil and the obtaining of a single soil block (monolith) extending from the surface to a depth of 3 to 6 feet. The monolith is of such dimensions, 2.5 feet wide and 3 inches thick, that it can be removed from the trench and taken to the laboratory without special equipment.

The monolith is marked out on the vertical trench wall directly beneath a representative bunch or sod of grass to be studied. With appropriate knives and spades the soil at the sides and beneath the monolith is removed to such a distance into the wall that the column of soil protrudes at least 3 inches into the trench. The monolith is tightly incased in a special open box or frame before it is cut from the trench wall and taken to the laboratory. This prevents cracking of the soil column and breaking of the roots. The soil is removed from the box by a process of repeated soaking, often for several days, and gentle washing, mostly under water. This is accomplished even when the soil is extremely compact or contains a claypan. During this process one may study the intimate relations of soil and roots. Roots remain unharmed and in their natural position in the water after the soil has been washed away. They are mounted on black felt cloth and photographed. They may then be sectioned in such a manner that the dry weight of 
the root-mass at $0-6$ inches, 1 to 2 feet, or at any other soil depth may be ascertained. A brief description of the method is given in Science (16) and a more detailed one in Ecological Monographs (17). By this method many range grasses in numerous soil types have been studied (20).

\section{Degeneration of Prairie}

A survey of prairie vegetation in eastern Nebraska, western Iowa, and contiguous portions of the four adjacent states was made in 1928-33 (18). The manner in which prairie degenerated under grazing into various types of pastures was also observed. The native pastures in this 60,000 square-mile area were classified into four distinct types according to the degree of degeneration of the native vegetation (19).

Briefly, the excellent or high-grade pastures consist almost entirely of climax grasses well liked by livestock. These are chiefly little and big bluestem, Andropogon scoparius and $A$. furcatus. But needle grass (Stipa spartea), prairie dropseed (Sporobolus heterolepis), numerous other grasses, and a host of legumes and other herbaceous plants (forbs) occur.

In the good or medium-grade pastures Kentucky bluegrass (Poa pratensis) or short grasses - blue grama (Bouteloua gracilis) and buffalo grass (Buchloe dactyloides) - or alternating areas of these equal or exceed the usual prairie species. They form the background or matrix of the vegetation. The original prairie species are clearly on the decline, although still abundant. The cover of grass is yet well intact.

The fair-grade pasture differs from the preceding in having a practically pure stand of bluegrass or short grass. Little bluestem has usually disappeared. In the best pastures the cover may be well intact but frequently it is broken. Both perennial and annual weeds are abundant.

In poor or low-grade pastures, areas of grass alternate frequently with bare ground or soil clothed only with weeds. Prairie forbs, with few exceptions, have disappeared. Both bluegrass and the short grasses are so severely grazed that the stand is thin. Many places are trampled bare. The cover is open almost everywhere.

These pasture types are easily recognized. They have the same general appearance throughout this very large tract of true prairie. Over most of the area the pastures are small (40 to 80 acres), uniformly grazed, and usually contain only a single pasture type. But in larger ones, where distance to water is greater, two or even three types may occur. Unlike the preceding they do not stop at the fence line, but one grades gradually into the other. It was in such a range that the studies on amount and distribution of roots were made.

The Pasture

The pasture is 4.5 miles west and 5 miles north of the University of Nebraska. It is a mile long, north to south, and a half mile in width. About 30 acres in the southwest corner have been broken and cultivated, hence the area is approximately 290 acres. The topography is that of rolling upland. Hills 50 to 130 feet high are separated by deep ravines (Fig. 1). These are dry except for a few days after rains. An exception occurs near the south end of the pasture where underground seepage produces a small but continuous stream of water. Two artificial ponds are located at the lower end of this ravine. The occurrence of water in only one place results in a very unequal distribution of grazing. This is accentuated by steepness of the hills, which often have slopes of 9 to 11 percent, and even steeper banks of 
ravines which must be crossed by the livestock.

Grazing began in this prairie in 1903, although hay was cut in fall where grazing had been light (usually in the north end) and the topography permitted. Originally the vegetation was similar in all parts of the pasture, the cover being less dense, of course, on the ridges. But after several years of grazing it became clear that production in the south part was declining. for each 2.54 acres. This is far greater than that recommended by experienced cattlemen, which is 5 to 7 acres per animal unit (2). Grazing began between April 15 and May 10, and ended late in October. The horses, however, had access to the pasture all winter. Since this heavy stocking was more or less concentrated in the south end of the pasture, it could result only in overgrazing and deterioration of this part.

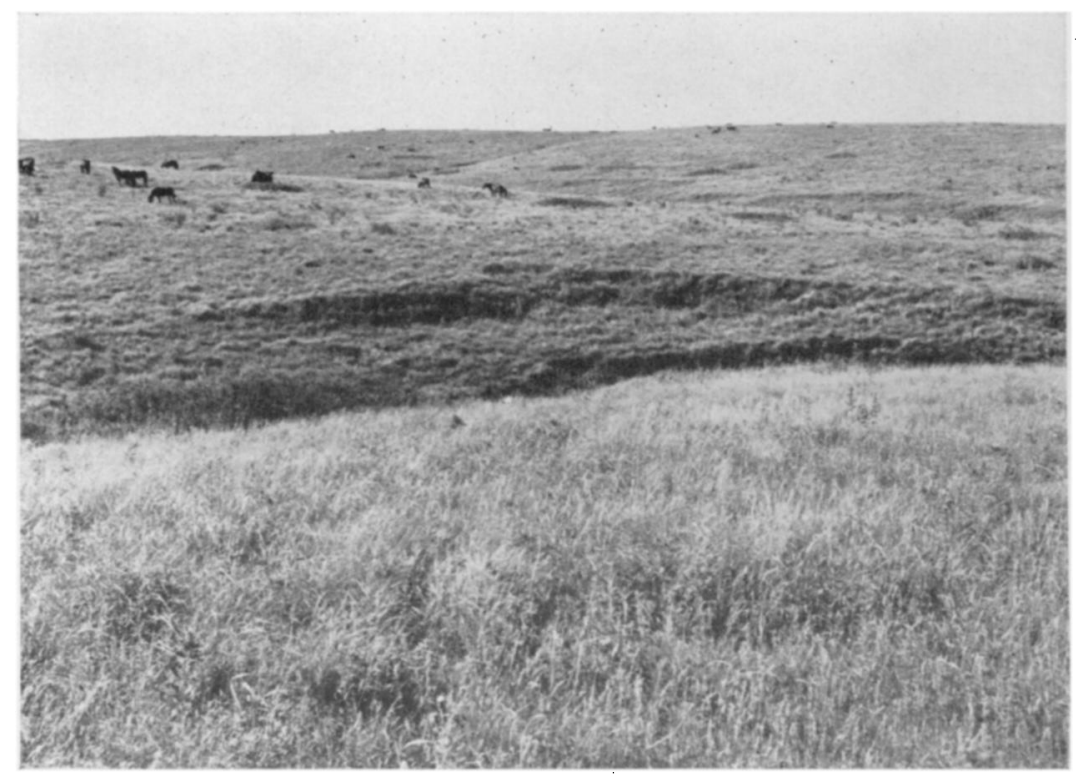

Fig. 1. General view of the north end of the pasture showing the rolling topography and thick cover of vegetation. The horses are grazing in high-grade vegetation near the north end of the pasture and farthest from the ponds. Cattle are scattered widely over a mid-grade type on the hills southward. Photo. August, 1947.

This occurred because grazing was always more intense in that area, adjacent to the farmyard where water and salt could be obtained. The pasture has never been partitioned by fences. The rate of stocking in the past 47 years has been very constant according to the owner, Mr. R. J. Black, irrespective of seasonal growth of vegetation, markets, etc. About 100 animal units of cattle and 14 of horses were carried each year. The rate is one animal
In 1949, high-grade pasture was confined largely to the northern one-fourth of the prairie. Mid-grade type covered most of the central portion; much of the southern part of the pasture was only fair to poor. The average composition of the vegetation in the high-grade portion was 36 percent little bluestem, 24 bluegrass, 20 big bluestem (total 80 percent), and 0.1 to 5 percent each of about a dozen other prairie grasses. Forbs composed less than 
2 percent of the cover. ${ }^{2}$ The soil mulch was heavy.

In medium-grade pasture little bluestem had decreased to 19 percent and big bluestem to 10 . But bluegrass had correspondingly increased to form nearly half (45 percent) of the cover. Side-oats grama (Bouteloua curtipendula) composed 7 percent and purple lovegrass (Eragrostis spectabilis) about 9 percent of the cover. About 3 percent was forbs. A moderate soil mulch occurred.

Composition of the lower grades of pasture (fair to poor) was much more variable. Little bluestem and many other climax grasses had disappeared and numerous weedy grasses had invaded. The forb population (mostly of weeds) composed 11 percent of the vegetation. The soil mulch was light, sometimes there was none. Where the roots were excavated nearly all of the vegetation was bluegrass and blue grama.

\section{Root Systems from the Same Soil in Three Grades of Pasture}

The first monolith was taken on a typical north slope in the high-grade part of the pasture. The sample was selected according to the average composition of the vegetation in this part. The sample was mostly little bluestem but also included about 15 percent big bluestem. Smaller amounts of bluegrass, side-oats grama, and other species were present (Fig. 2). The thorough occupation of the soil by the roots, especially the upper soil, and their uniform decrease with depth is representative of this type of vegetation which has been examined in many places. Above ground the bluestems were 10 to 14 inches high when the monolith was taken, about June 5, 1949.

In the mid-grade pasture a typical area

2 Data from unpublished Master's Thesis by L. G. Butler, University of Nebraska, 1948. was selected on a mid-slope with a northern exposure. About half of the area was occupied by bluegrass. Much of the remaining little bluestem had been more or less weakened by prolonged grazing. Hence this monolith was taken so as to include about half bluegrass and portions of both a vigorous and a weakened bunch of little bluestem as well (Fig. 3).

The soil in the two trenches dug to secure the root samples varied but little, as did also that from a third excavation in low-grade pasture. The description of this Carrington silt loam is from the midgrade type. It is given here since it has recently been ascertained that the nature of the soil profile often has a profound effect upon the distribution of roots in the soil. For example, percentage of the weight of the root system of big bluestem occurring in the surface 6 inches has been found to vary from 63 to 80 in Crete silt loam and Crete silty clay loam, respectively. In some soil types with a claypan, roots of western wheatgrass (Agropyron smithii) below the compacted layer (B horizon) may branch so greatly that their weight is a third greater than that of roots in a similar volume of soil in the B horizon (17).

The upper part of the soil to a depth of 28 inches appears to have developed from a thin layer of loess. Below 28 inches the parent material apparently is part of an old soil that was developed largely from Kansan glacial till. Below 38 inches all of the soil material appears to be weathered from glacial till. It contains small pebbles and grit mixed with clay and silt in varying proportions. Nowhere in the first five feet was any calcium carbonate in evidence. ${ }^{3}$

3 The soil profile was described by B. H. Williams of the Division of Soil Survey, U. S. Department of Agriculture, and the Conservation and Survey Division, University of $\mathrm{Ne}$ braska. 


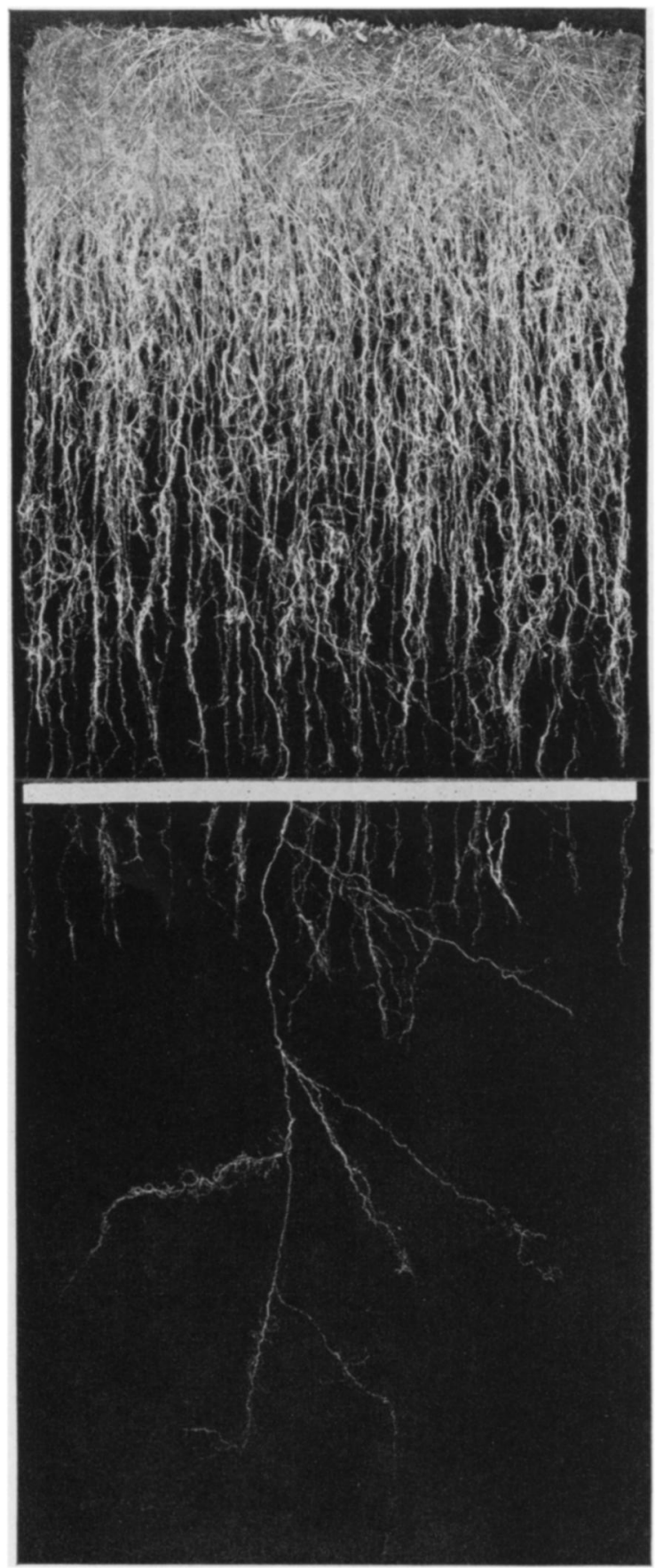

FIG. 2. Roots from a monolith of soil 2.5 feet wide, 3 inches thick, and 6 feet deep. It was taken in two three-foot sections. The white bar shows the depth of the upper section of the monolith. The deepest grass roots were about 4 feet long. Roots of a prairie legume (Psoralea floribunda) extended even deeper. 


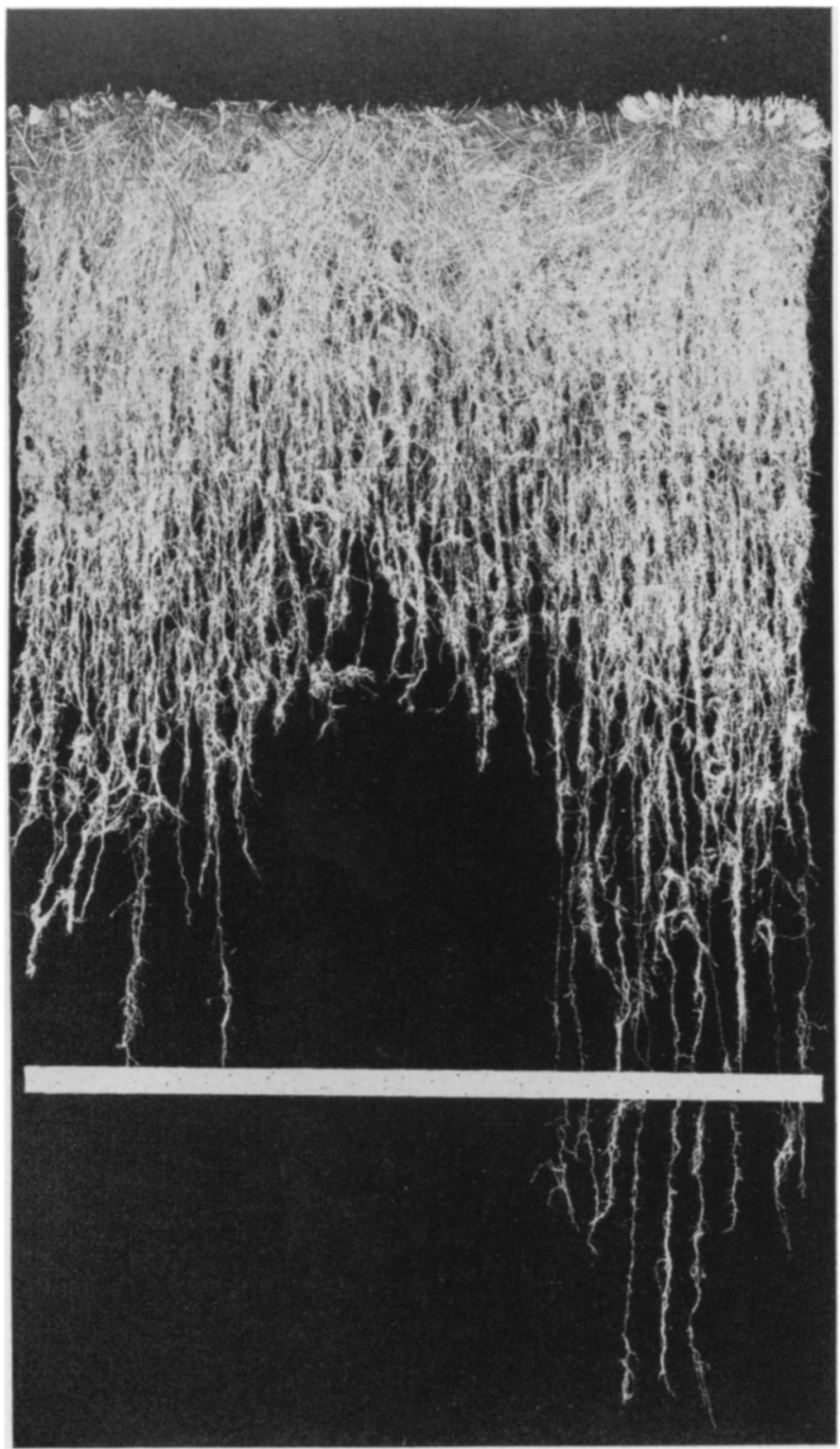

Fra. 3. Typical root distribution in the mid-grade pasture. From left to right are shown a nonvigorous bunch of little bluestem, bluegrass, and a vigorous (scarcely grazed) bunch of little bluestem. The 2-foot depth of roots is about normal in this soil for bluegrass. Differences in root habit of the bluestem may be attributed to differences in vigor resulting from grazing. 


\section{Hor-
izon Depth, in. Description (Color of soil when dry) \\ $A_{1} \quad 0-4$ Dark grayish brown fine gran- ular heavy silt loam; $\mathrm{pH}$ (with Soiltex) 6.5 \\ $4 \quad-10.5$ Slightly lighter grayish brown heavy silt loam; granular; $\mathrm{pH} 6.5$ \\ $B_{1}$ 10.5-15.5 Dark grayish brown silty clay loam; granular; $\mathrm{pH} 6.5$ \\ $\mathrm{B}_{2}$ 15.5-28 Pale brown coarse granular silty clay; with a tendency to cleave vertically; $\mathrm{pH} 6.5$ \\ $\begin{array}{lll}28 & -38 \quad \text { Brown and mottled light gray }\end{array}$ to yellowish brown heavy silty clay loam; strongly prismatic breaking down into half-inch sharply angular blocks; $\mathrm{pH}$ 6.5 \\ $\begin{array}{ll}38 & -48\end{array}$ \\ Brownish yellow, mottled with brown and light gray heavy sandy clay or clay with pebbles; $\mathrm{pH} 7.0$ \\ $\begin{array}{llll}\text { C } & 48 & -60 & \text { Mottled light gray heavy clay }\end{array}$ loam with pebbles; not so heavy as horizon above; mas- sive; $\mathrm{pH} 7.5$}

In the low-grade pasture bluegrass and blue grama, except for weeds, clothed large portions of the soil. A trench was dug and a monolith secured on a hillside in such a manner as to include about half bluegrass and half blue grama. No little bluestem was present here (Fig. 4).

Comparison of figures 2, 3 , and 4 shows remarkable changes in root depths in the three grades of pasture. As the native mid and tall grasses weakened and died and were replaced by low-growing bluegrass and blue grama, both depth of soil occupied by roots and the amount of root material decreased greatly. Oven-dry weights of roots and percentage decrease at each soil level are shown in Table 1.

Distribution of the roots followed the usual pattern for little bluestem. Weight of roots decreased rapidly but regularly with depth and no visible irregularities were caused by changes in the soil profile, which were also gradual. About 85 percent of the total root weight occurred in the A horizon (0 to 10.5 inches depth) and 15 percent in the $\mathrm{B}$ horizon (10.5 to $60+$ inches).

\section{TABLE 1}

Dry weight in grams of underground plant material at the several soil depths in three grades of pasture and percentage decrease from the high-grade type

\begin{tabular}{|c|c|c|c|c|c|}
\hline DEPTH & $\begin{array}{l}\text { HIGH- } \\
\text { GRADE }\end{array}$ & $\begin{array}{l}\text { MTD- } \\
\text { GRADE }\end{array}$ & DECREASE & $\begin{array}{l}\text { LOW- } \\
\text { GRADE }\end{array}$ & DECREASE \\
\hline$f t$. & $g m$. & $g m$. & $\%$ & $g m$. & $\%$ \\
\hline $\begin{array}{ll}0 & -0.5\end{array}$ & 65.50 & 52.20 & 20 & 28.14 & 57 \\
\hline $.5-1$ & 9.10 & 8.55 & 6 & 4.13 & 55 \\
\hline $\begin{array}{ll}1 & -2\end{array}$ & 6.93 & 6.52 & 6 & 2.66 & 62 \\
\hline $\begin{array}{ll}2 & -3\end{array}$ & 2.39 & .95 & 60 & .14 & 94 \\
\hline $\begin{array}{ll}3 & -4\end{array}$ & .40 & .17 & 58 & - & 100 \\
\hline Total. & 84.32 & 68.39 & 19 & 35.07 & 58 \\
\hline
\end{tabular}

The chief cause of the greater weight of materials in the surface $0-0.5$ foot compared with that of the second layer is the great abundance of stem-bases and rootstocks near the soil surface. These often equal the weight of the roots. They, of course, are lighter in worn-down bluestems, and especially in bluegrass and blue grama. But the roots at all depths decreased greatly and especially those in the third and fourth foot. Here losses of 60 to 100 percent were found. Decrease in total dry weight of root systems, was also very marked, at first it was 19 and then 58 percent. Loss of yield of 50 percent in the annual forage crop has been ascertained when bluestems are replaced by bluegrass (13). Loss of roots in the deeper soil or death of all the roots in this part results in a much restricted volume of soil from which water and nutrients may be absorbed.

The low root-weight of bluegrass and blue grama is not unusual. In another low-grade, upland pasture similar monoliths were taken in Carrington silty clay 


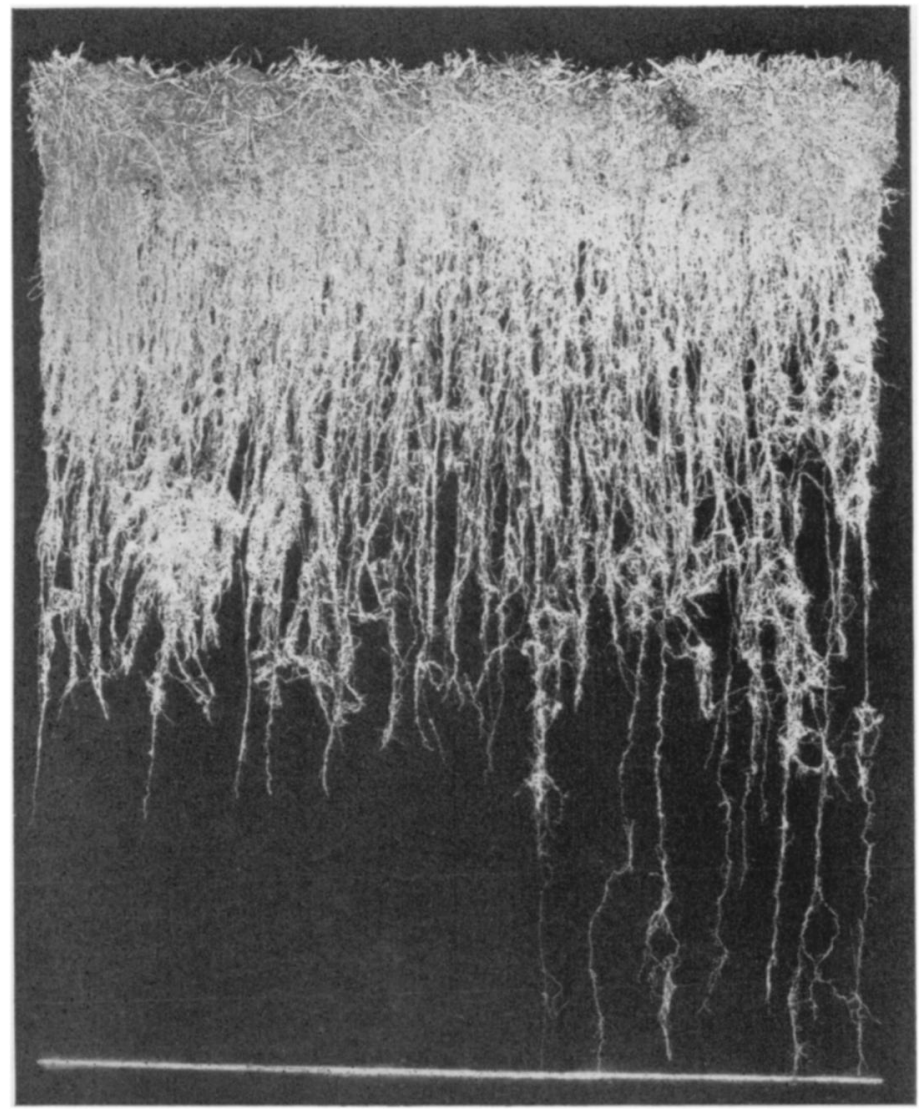

Fig. 4. Root development of bluegrass (left) and blue grama (right) on a slope similar to the preceding in the low-grade pasture. As in all the trenches, the soil was moist far below the greatest depth of the roots. The dense mats of roots furnished by the two grasses are very similar. Roots of blue grama reached a depth of about 3 feet.

loam. The total weight of roots was only 28.15 grams. Here again all but a very few roots were found in the surface 2 feet of soil. Conversely, the root-weight has been found to be greater elsewhere, especially in deep lowland soil. Monoliths were taken in the high-grade pasture on low, level land near Lincoln. The rich, deep, alluvial soil was Wabash silt loam and the grass examined was big bluestem. Here the roots made a wonderful development in the first three feet of soil, and many penetrated to 6 feet in depth. The total root-weight was 91.15 grams. This exceeds the weight in the upland sample by about 8 percent. In a portion of the pasture where big bluestem had been grazed out and replaced by a nearly pure stand of bluegrass, a second monolith was taken. The root-mass was very dense in the surface 2 feet and numerous roots extended well into the third foot. Total root-weight (55.61 grams) exceeded the bluegrass-grama root-weight in the present study by 59 percent. Thus, rootweight of a species, like that of the tops, varies greatly from place to place, according to soil type but especially according to the proper use or abuse of the vegetation. 


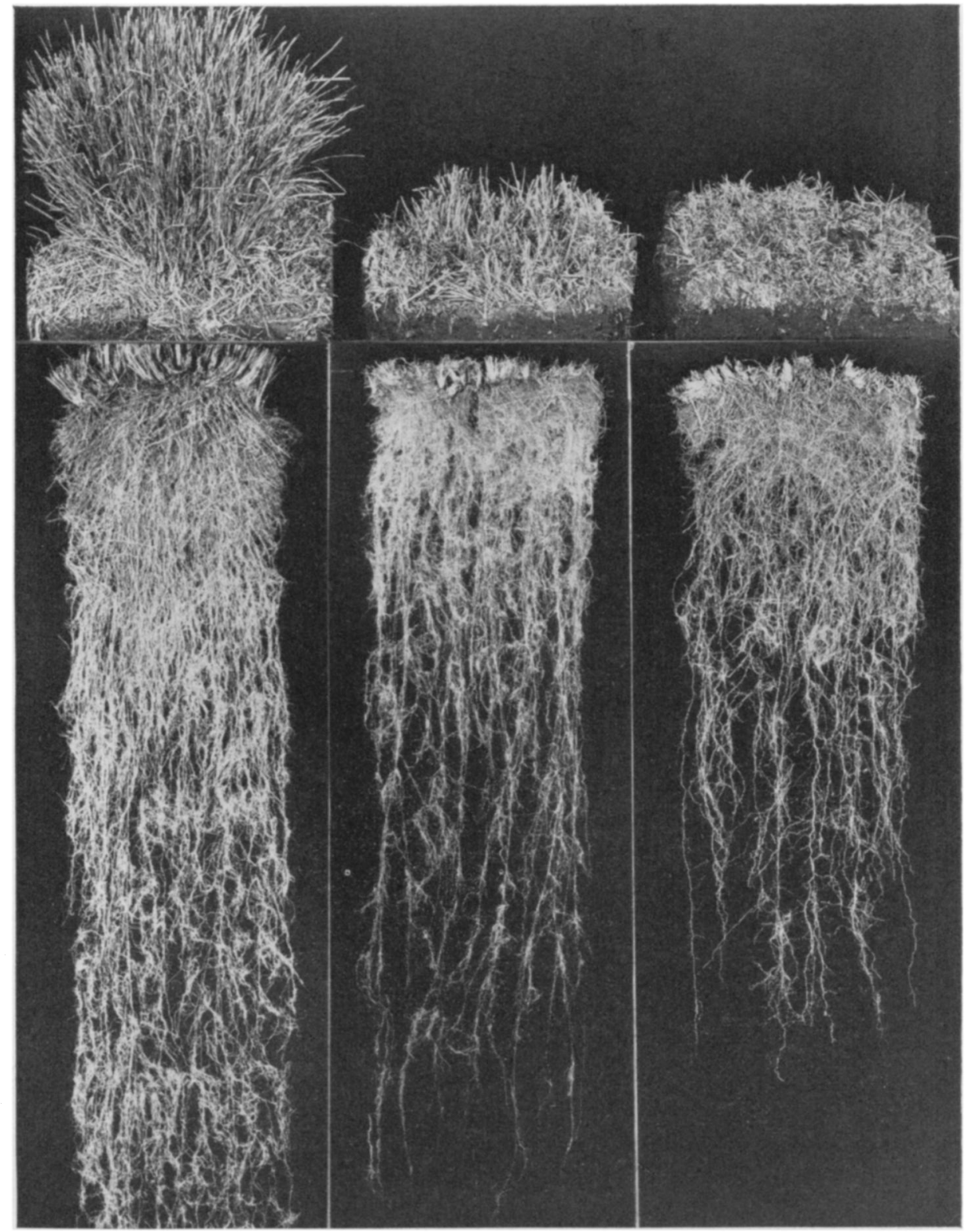

Fig. 5. Typical bunches of little bluestem from high-grade, mid-grade, and low-grade pasture. These are very similar to those from which the root systems (below) were obtained in June, 1949. Much of the grass in the block of sod on the right is dead.

Deterioration of Little Bluestem

The degeneration of the bluestem grasses under different intensities of grazing was further examined. This was done by the study of representative individual bunches. One bunch of little bluestem was selected from a portion of the pasture where grazing for several years had been very light or none. The last year's stubble was thick, continuous, and 8 inches tall. 
The bluestem was in a very vigorous condition. A second bunch was selected in the mid-grade area. Apparently it had been grazed closely for at least two years. There was only a little debris left from preceding years. The individual tufts composing the bunch were abundant but more or less separated by bare spaces; hence the crown was somewhat open. The third clump was from a portion of a low-grade area where little bluestem still persisted but in a much weakened condition. The bunch was very open, much bare soil was exposed because of this and the lack of a good mulch. The individual tufts of grass were short and much stunted. Many fragments of dead tufts were present. A monolith of soil 12 inches wide and 4 feet in depth was taken directly below each bunch. After the roots were freed of soil each root system was photographed (Fig. 5).

Decrease in the density of the rootmass at all levels from the high-grade to the low-grade pasture is clearly evident. The roots were almost 5 feet deep in the first sample, about 4 feet in the second, but they extended to only about 3 feet in the third. The dense crown of the first sample was separated only with much difficulty in washing away the soil. The more open crown of the second bunch was easily torn apart, while the third was so nearly decayed that it fell apart as the soil of the soaked sod was washed away (Table 2).

The high weight of the first sample in the shallow soil is characteristic of this species and is due in a large measure to the weight of underground stem-bases and short rootstocks. Decrease in weight at all depths in the second sample is very great. The weight, compared with that of the first sample, decreases regularly with depth from 19 to 91 percent (Table 2). Total weight of the second sample was 55 percent less than the first. In the second sample the roots were not only fewer than in the first but also finer. Their diameter was only a half to a third as great. Some dead roots were found. In the third sample differences were even more marked. Branches were fewer, many roots were dead, and debris from decaying roots was abundant. There were no roots in the fourth foot. They were 83 percent less in the third, compared with the high-grade sample, 59 in the second foot, and 40 percent in the second six-inches. This same sequence of decreasing weight occurred in the second sample. Thus, it seems clear that root deterioration is from the tips

TABLE 2

Dry weight of underground plant materials of little bluestem at the several depths in the three grades of pasture and percentage decrease from the high-grade type

\begin{tabular}{|c|c|c|c|c|c|}
\hline DEPTH & $\begin{array}{l}\text { HIGH- } \\
\text { GRADEE }\end{array}$ & $\begin{array}{l}\text { MID- } \\
\text { GRADE }\end{array}$ & DECREASE & $\begin{array}{l}\text { LOW- } \\
\text { GRADEE }\end{array}$ & DECREASE \\
\hline ft. & $g m$. & $g m$. & $\%$ & $g m$. & $\%$ \\
\hline $\begin{array}{ll}0 & -0.5\end{array}$ & 44.60 & 18.99 & 57 & 10.17 & 77 \\
\hline $.5-1$ & 2.74 & 2.21 & 19 & 1.63 & 40 \\
\hline $\begin{array}{ll}1 & -2\end{array}$ & 2.59 & .61 & 38 & 1.07 & 59 \\
\hline $\begin{array}{ll}2 & -3\end{array}$ & 1.20 & .64 & 47 & .21 & 83 \\
\hline $\begin{array}{ll}3 & -4\end{array}$ & .75 & .07 & 91 & - & - \\
\hline Total & 51.88 & 23.52 & 55 & 13.08 & 75 \\
\hline
\end{tabular}

upward toward the crown. This sequence has been noted several times and the actual process was observed in Sudan grass as a result of frequent clipping (3).

In previous studies of pastures, vigorous bunches of grasses of several species have been permanently located, measured, and their waning and death recorded. This may occur after 2 to 3 years where summer-long grazing is heavy. The dying and dead roots have been studied, but never with the clarity and definiteness that this method affords. It requires 2 to 3 years in eastern $\mathrm{Ne}$ braska for the roots and rootstocks of native grasses to decay so completely 
that they cannot be distinguished from the soil (10). this species in the low-grade pasture (Fig. 6). The process of deterioration of

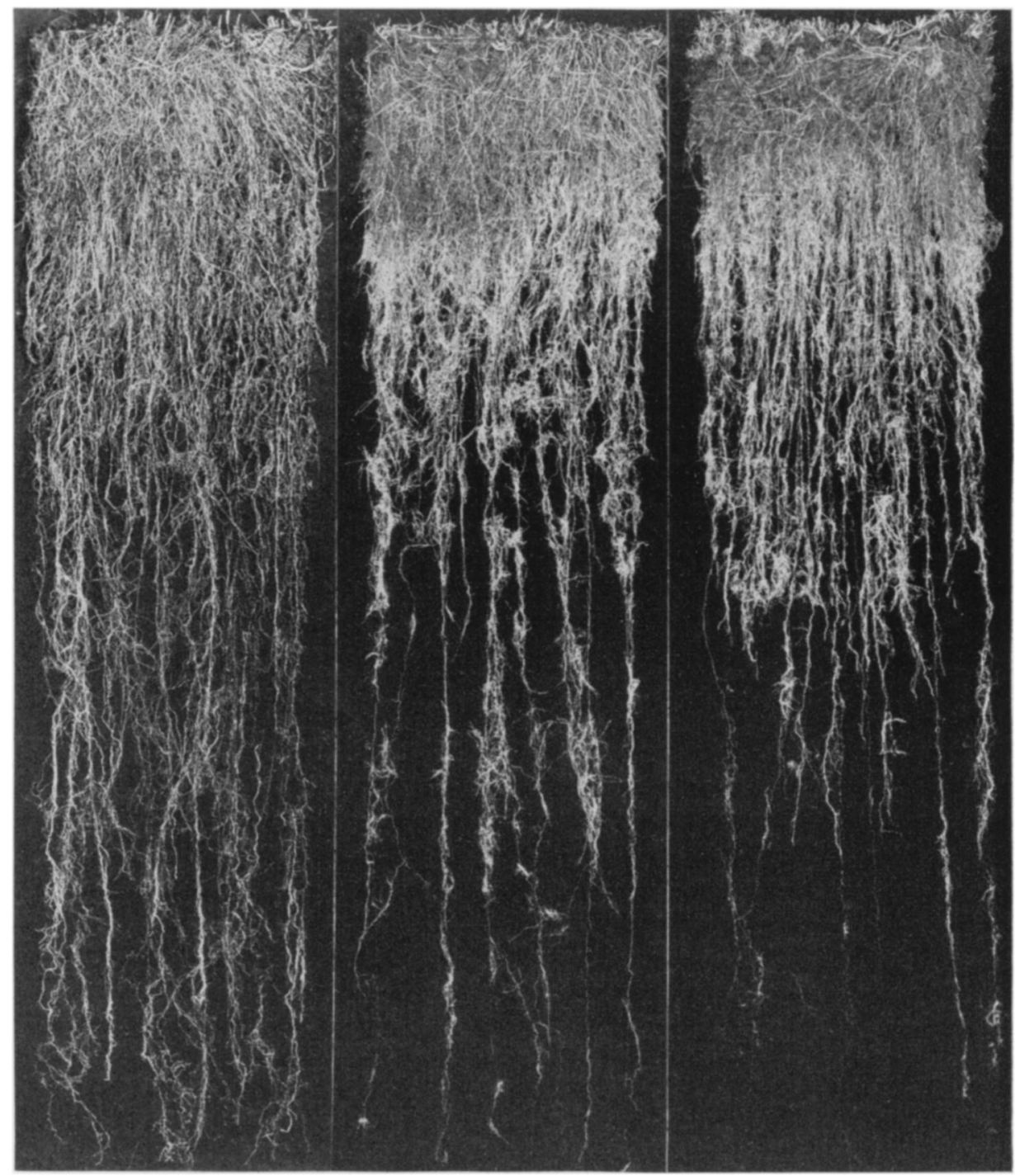

Fig. 6. Root systems from 4-foot monoliths of big bluestem in pastures of high-grade, midgrade, and low-grade, respectively. The last sod (right) was invaded by bluegrass which added greatly to the mass of roots in the surface two feet. Total root-weight of the bluestem roots alone is only about half that from the mid-grade pasture.

Deterioration of Big Bluestem

Similar studies were made on root deterioration of big bluestem, except that bluegrass invaded the area occupied by the root system was about the same as that of little bluestem (Table 3).

Here the loss in root materials below the first foot again increased with depth. 
Weight of the root system in mid-grade pasture was only half that in high-grade, and in low-grade pasture it was only onefourth as great. little bluestem was taken from a highgrade native pasture on May 17, 1945. It was almost identical with that shown in figure 5. The previous year's stubble

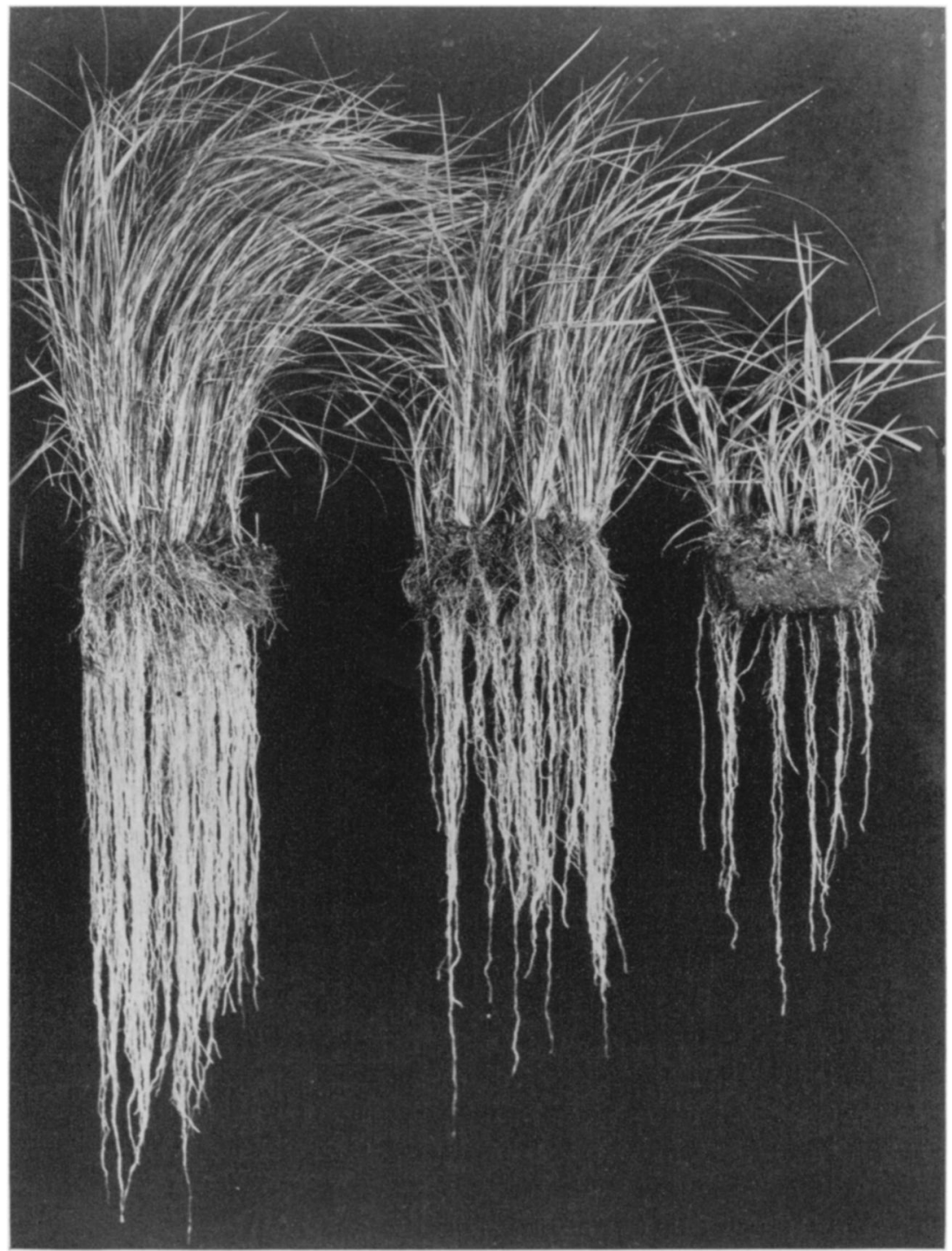

Fig. 7. New growth of roots and tops of little bluestem six weeks after transplanting the sods on May 17. The sods were each 6 inches long, 4 inches wide, and 3 inches deep but taken from a high-grade, mid-grade, and low-grade pasture, respectively.

A Direct Measure of Vigor

The loss of vigor of bluestem grasses has been shown in another way in previous studies (14). A well-filled bunch of was 6 inches tall and the new growth was also 6 inches high. A second bunch was from a mid-grade pasture. The center of the bunch was dead and the crown con- 
sequently open as in figure 5, but a moderately thick new growth was about 2.5 inches high. The third bunch was from a much abused, low-grade pasture on similar soil. The central part of the bunch was dead; only a few weak shoots 0.5 to 1.5 inches tall grew on the periphery. The thin stand and weak plants were also similar to those in figure 5 .

The sods were transplanted into fertile well-watered soil in good tilth in metal lined, wooden boxes $10 \times 10$ inches in width and 24 inches deep. Each sod was cut exactly 6 inches long, 4 inches wide, and 3 inches deep. After 6 weeks' of

TABLE 3

Dry weight of underground plant materials of big bluestem at the several depths in three grades of pasture and percentage decrease from that in the high-grade area

\begin{tabular}{|c|c|c|c|c|c|}
\hline DEPTH & $\begin{array}{l}\text { HIGH- } \\
\text { GRADE }\end{array}$ & $\underset{\text { GRADE }}{\text { MTD- }}$ & DECREASE & $\begin{array}{c}\text { LOW- } \\
\text { GRADE }\end{array}$ & DECREASE \\
\hline$f t$. & $g m$. & $g m$. & $\%$ & $g m$. & $\%$ \\
\hline $\begin{array}{ll}0 & -0.5\end{array}$ & 28.70 & 13.55 & 53 & 7.05 & 75 \\
\hline $.5-1$ & 3.72 & 2.53 & 32 & 1.15 & 69 \\
\hline $\begin{array}{ll}1 & -2\end{array}$ & 2.60 & 1.89 & 27 & .95 & 63 \\
\hline $\begin{array}{ll}2 & -3\end{array}$ & 1.19 & .59 & 50 & .29 & 76 \\
\hline $\begin{array}{ll}3 & -4\end{array}$ & .46 & .20 & 57 & .14 & 70 \\
\hline Total & 36.67 & 18.76 & 49 & 9.58 & 76 \\
\hline
\end{tabular}

growth one side of each box was removed and the soil was carefully washed from the roots. Then both tops and roots were photographed (Fig. 7). The dry weight of the new tops was $30.22,12.89$, and 1.87 grams, respectively. Dry weight of new roots below the old sod was $4.70,1.72$, and 0.33 grams in the same order, a ratio of 14 to 5 to 1 . Roots were progressively thinner with decreasing vigor.

Experiments with big bluestem and several other species of pasture grasses gave similar results, all showing the evil effects of overgrazing. Dry weight of tops produced by weakened plants was 32 to 84 percent less than that of plants which had good to fair vigor. New roots were always shorter and less branched, and dry weight was 28 to 94 percent less than that of vigorous plants of the same species. Just as the forage yield may be increased by good pasture management, so too the root systems of the grasses will be improved somewhat in proportion. A good top that produces much nutritious forage and a good root system that can withstand drought and store much food for early growth in spring go hand in hand. A depleted range of non-vigorous grasses is usually also one in which the root systems are absorbing water and nutrients only in the upper portion of the soil.

\section{LITERATURE CITED}

1. Albertson, F. W. 1937. Ecology of mixed prairie in western Kansas. Ecol. Monog. $7: 481-547$.

2. Aldous, A. E. 1938. Management of Kansas bluestem pastures. Jour. Amer. Soc. Agron. 30:244-253.

3. Peralta, F. 1935. Some principles of competition as illustrated by Sudan grass, Holcus sorghum sudanensis (Piper) Hitch. Ecol. Monog. 5:355-404.

4. Tolstead, W. L. 1942. Vegetation of the northern part of Cherry county, Nebraska. Ecol. Monog. 12:255-292.

5. Weaver, J. E. 1915. A study of the root systems of prairie plants of southeastern Washington. Plant World 18:227-248, 273292.

6. ——_ 1917. A study of the vegetation of southeastern Washington and adjacent Idaho. Univ. Studies, Univ. Neb., Lincoln, 17 (1) : 1-114.

7. —_— 1919. Ecological relations of roots. Carn. Inst. Wash. Pub. 286.

8. _— 1920. Root development in the grassland formation. Carn. Inst. Wash. Pub. 292.

9. _ — 1926. Root development of field crops. McGraw-Hill Book Co. Inc. New York.

10. —— 1947. Rate of decomposition of roots and rhizomes of certain range grasses in undisturbed prairie soil. Ecology $28: 221-240$. 
11. - - And F. W. Albertson. 1943. Resurvey of grasses, forbs, and underground plant parts at the end of the great drought. Ecol. Monog. 13:63-117.

12. $\rightarrow--$, AND W. E. Bruner. 1948. Prairies and pastures of the Dissected Loess Plains of central Nebraska. Ecol. Monog. 18:507-549.

13. - — AND R. W. Darland. 1945. Yields and consumption of forage in three pasture types; an ecological analysis. Neb. Conserv. and Surv. Div. Bul. 27.

14. —_ AND _— 1947. A method of measuring vigor in range grasses. Ecology 28:146-162.

15. ——, AND —— 1948. Changes in vegetation and production of forage re- sulting from grazing lowland prairie. Ecology $29: 1-29$.

16. —— AND _— 1949. Quantitative study of root systems in different soil types. Science 110 (No. 2850) :164-165.

17. ———, AND ——— 1949. Soil-root relationships of certain native grasses in various soil types. Ecol. Monog. 19 :303338 .

18. - - - ANd T. J. FitzPatrick. 1934. The prairie. Ecol. Monog. 4:109-295.

19. - - ANd W. W. Hansen. 1941. Native midwestern pastures-their origin, composition, and degeneration. Univ. Neb. Cons. and Surv. Div. Bul. 22.

20. - - AND J. Voigt. 1950. Monolith method of root-sampling in studies on succession and degeneration. In press. 